\title{
Analisis tentang Pelaksanaan Sistem Jaminan Sosial Kesehatan Pasca Putusan Mahkamah Konstitusi No. 07/PUU-III/2005
}

\author{
Muh. Kadarisman \\ Magister Ilmu Administrasi Pascasarjana Universitas Muhammadiyah \\ Jl. KH. Ahmad Dahlan, Ciputat, Jakarta Selatan 15419. \\ kadarisman.bkn@gmail.com
}

\begin{abstract}
This study aims at analyzing the implementation of Law No. 40 of 2004 related to the Health Social Security after the Constitutional Court decision No. 07 / PUU-III / 2005. The reseacher uses library research method with content analysis approach. The research result highlights that: the implementation of Law No. 40 of 2004 related to the Health Social Security after the Constitutional Court decision No. 07 / PUU-III / 2005, whose implementation is entrusted to BPJS is still far from fairness for all. The application of Health Social Security BPJS is still problematic in many ways, among which since it implements a tiered service flow prior to the hospital, that is the participants must first check into the first-level health facilities (health centers) before being referred to the hospital. Another problem is regarding the complexity of the service flow of BPJS for implementing a tiered service flow.
\end{abstract}

Keywords: Health social security, the constitutional court decision

\begin{abstract}
Abstrak
Penelitian ini bertujuan menganalisis pelaksanaan UU No. 40 Tahun 2004 terkait Jaminan Sosial Kesehatan pasca Putusan MK No. 07/PUU-III/2005. Metode penelitian yang digunakan adalah library research. Penelitian ini menggunakan metode analisis isi (content analysis). Penelitian menyimpulkan: pelaksanaan UU No. 40 Tahun 2004 terkait Jaminan Sosial Kesehatan pasca Putusan MK No. 07/PUUIII/2005, yang pelaksanaannya dipercayakan pada BPJS Kesehatan masih jauh dari makna keadilan. Penerapan BPJS Kesehatan masih memiliki persoalan dalam banyak hal, di antaranya karena menerapkan alur pelayanan berjenjang yaitu sebelum ke rumah sakit, peserta wajib terlebih dulu ke fasilitas kesehatan tingkat pertama (Puskesmas). Masalah lain, adalah rumitnya alur pelayanan BPJS Kesehatan karena menerapkan alur pelayanan berjenjang.
\end{abstract}

Kata kunci: Jaminan sosial kesehatan, putusan mahkamah konstitusi 


\section{Pendahuluan}

Undang Undang Dasar (UUD) Negara Kesatuan RI 1945 Pasal 28H, ayat (3) (Amandemen Kedua) menyatakan bahwa "Setiap orang berhak atas jaminan sosial yang memungkinkan pengembangan dirinya secara utuh sebagaimana manusia yang bermartabat". 1Selanjutnya, Pasal 34 ayat (2) (Amandemen Keempat) menyatakan sebagai berikut, "Negara mengembangkan sistem jaminan sosial bagi seluruh rakyat dan memberdayakan masyarakat yang lemah dan tidak mampu sesuai dengan martabat kemanusiaan". ${ }^{2}$ Di samping itu, Ketetapan MPR RI No. X/MPR/2001 tentang Laporan Pelaksanaan Putusan MPR RI oleh Lembaga Tinggi Negara pada Sidang Tahunan MPR RI 2001 juga menugaskan kepada Presiden untuk membentuk sistem jaminan sosial nasional dalam rangka memberi perlindungan sosial yang lebih menyeluruh dan terpadu. ${ }^{3}$

Pada 2004, DPR telah mensahkan UU No. 40 Tahun 2004 tentang Sistem Jaminan Sosial Nasional (SJSN). ${ }^{4}$ Sistem ini memberi jaminan perlindungan dan kesejahteraan sosial bagi seluruh rakyat. Setiap warga negara dijamin haknya untuk hidup layak apabila terjadi situasi yang tidak menguntungkan serta dapat mengakibatkan hilang atau berkurangnya pendapatan, baik karena sakit, kecelakaan, kehilangan pekerjaan, usia lanjut dan pensiun. UU tersebut mengatur jaminan sosial dengan pendekatan skema asuransi yang mewajibkan bagi pekerja formal untuk mengikuti jaminan sosial pada aspek jaminan kesehatan, jaminan kecelakaan kerja, pemutusan hubungan kerja, jaminan hari tua dan pensiun serta jaminan kematian.

UU No 40 Tahun 2004 menyebutkan bahwa dalam penerapan SJSN berbasis pada asuransi. Selain itu, dalam program Badan Penyelenggara Jaminan Sosial (BPJS), setiap peserta yang dinilai mampu, seperti buruh, wajib membayar iuran yang besarannya ditetapkan pemerintah. Padahal, dalam sistem asuransi yang dikelola Jamsostek saat ini, pekerja tidak harus membayar iuran karena

\footnotetext{
${ }^{1}$ Sekretariat Jenderal MPR RI, Undang-Undang Dasar Negara Republik Indonesia Tabun 1945, Cetakan Keempatbelas, Juni 2015, hlm. 107.

IIbid., hlm. 168.

${ }^{3}$ Ketetapan MPR RI No. X/MPR/2001 tentang Laporan Pelaksanaan Putusan MPR RI oleh Lembaga Tinggi Negara pada Sidang Tahunan MPR RI Tahun 2001

${ }^{4} U U$ No. 40 Tahun 2004 tentang Sistem Jaminan Sosial Nasional.
} 
sudah ditanggung oleh perusahaan atau pemberi kerja. Oleh karena itu, penggunaan mekanisme asuransi sosial atau tabungan sosial yang bersifat wajib atau compulsory insurance, adalah dibiayai dari kontribusi atau iuran yang dibayarkan oleh peserta. Dengan kewajiban menjadi peserta, sistem ini dapat terselenggara secara luas bagi seluruh rakyat, terjamin kesinambungannya dan profesionalisme penyelenggaraannya.

Peserta program ini adalah tenaga kerja di sektor formal, seperti pegawai negeri atau pegawai swasta. Fokus dalam pengembangan sistem perlindungan sosial diarahkan pada jaminan sosial dengan pendanaan bersumber dari asuransi sosial, bantuan sosial dan tabungan. Tantangan utamanya adalah bagaimana mengembangkan sistem jaminan sosial yang secara cepat mencakup sebanyakbanyak warga negara dan mengefektifkan bantuan sosial agar benar-benar dapat diterima oleh warga negara yang benar-benar membutuhkannya. Pengalaman di berbagai negara menunjukkan bahwa perluasan ini memerlukan komitmen pemerintah, penegakan hukum yang konsisten, dan terdapatnya sejumlah pekerja di sektor formal yang memadai jumlahnya.

Sistem perlindungan sosial pada akhirnya akan mendorong sebanyak mungkin warga negara yang mau dan mampu menjadi peserta jaminan sosial, sehingga warga negara yang memperoleh bantuan sosial, masyarakat yang tidak beruntung dan rentan atau Penyandang Masalah Kesejahteraan Sosial (PMKS) dan masyarakat miskin, yang menjadi kelompok sasaran pelayanan sosial menjadi semakin kecil. Semakin banyak warga negara yang tercakup dalam skema jaminan sosial akan memperkecil kemungkinan warga negara tersebut jatuh ke jurang kemiskinan manakala pendapatannya berkurang atau hilang tiba-tiba akibat suatu penyakit, PHK, kecelakaan, pensiun, atau sebab lain.

Selain itu, perlu terus diupayakan untuk mempertajam berbagai program bantuan sosial yang dilakukan oleh berbagai sektor agar bantuan sosial yang diberikan dapat tepat sasaran, terkoordinasi, efisien dan efektif. Setiap warga negara yang berpenghasilan, wajib menjadi peserta jaminan sosial yang dalam praktiknya dapat diprioritaskan pada hal-hal yang sangat mendesak dibutuhkan. Misalnya, program jaminan kesehatan dapat didahulukan daripada program jaminan kematian atau jaminan pensiun, sesuai dengan tingkat upah atau kemampuan ekonomi penduduk. 
Implementasinya menunjukkan, bahwa terjadi berbagai permasalahan di antaranya adalah belum adanya kepastian perlindungan dan jaminan sosial untuk setiap penduduk (WNI) agar dapat memenuhi kebutuhan hidupnya sebagaimana yang diamanatkan dalam Perubahan UUD 1945 tahun 2002, Pasal 34 ayat (2), yaitu "Negara mengembangkan Sistem Jaminan Sosial bagi seluruh rakyat". Perlindungan dan jaminan sosial yang ada saat ini belum mampu mencakup seluruh warga negara Indonesia. Misalnya, belum adanya perlindungan dan jaminan sosial bagi pekerja sektor informal.

Selanjutnya, belum adanya satu peraturan perundang-undangan yang melandasi pelaksanaan sistem perlindungan dan jaminan sosial secara lengkap dan terpadu. Masing-masing jenis perlindungan dan jaminan sosial yang ada saat ini dilandasi oleh UU dan atau Peraturan Pemerintah (PP) yang berbeda-beda. Hal ini menyebabkan penanganan skema perlindungan dan jaminan sosial yang ada masih terpisah-pisah, bahkan tumpang tindih. Di samping itu, good governance yang dipahami sebagai suatu penyelenggaraan manajemen pemerintahan yang solid dan bertanggung jawab yang sejalan dengan prinsip demokrasi dan pasar, pemerintahan yang efisien, serta pemerintahan yang bebas dan bersih dari kegiatan korupsi, kolusi, dan nepotisme $(\mathrm{KKN})^{5}$ belum berjalan dengan baik.

Terkait bahasan tentang ini, Miftah Thoha berpendapat, bahwa good governance merupakan tata pemerintahan yang terbuka, bersih, berwibawa, transparan dan bertanggung jawab. ${ }^{6}$ Secara konseptual dapat dipahami, bahwa good governance menunjukkan suatu proses yang memposisikan rakyat dapat mengatur ekonominya.7 Contohnya, asuransi kesehatan di-cover oleh PT JAMSOSTEK, PT ASKES, dan Jaminan Pemeliharaan Kesehatan Masyarakat (JPKM).Terakhir, bahwa skema perlindungan dan jaminan sosial yang ada masih terbatas, sehingga benefit (kuantitas dan kualitas) yang diperoleh juga masih terbatas. Bantuan sosial yang diberikan selama ini belum mencakup seluruh penduduk melaksanakan skema ini, sehingga pemanfaatannya belum optimal.

${ }^{5}$ I Gusti Ayu Ketut Rachmi Handayani, "Urgensi Peraturan Daerah Pengelolaan Daerah Aliran Sungai Bengawan Solo dalam Rangka Penguatan Fungsi Lingkungan Hidup dan Good Governance”, dalam Jurnal Hukum Ius Quia Iustum Vol. 20 No. 2, hlm. 263.

${ }^{6}$ Miftah Thoha, Birokrasi Pemerintahan Indonesia di Era Reformasi, Kencana Prenada Madia Group, Jakarta, 2008, hlm. 1-2.

7Dedi Mulyadi, Pelayanan Publik Dalam Konsep Good Governance, 2012, hlm. 2. 
Jaminan kesehatan bagi Pegawai Negeri Sipil (PNS) melalui PT ASKES dilandasi dengan UU No. 2 Tahun 1992 tentang Jaminan Kesehatan Bagi PNS Melalui PT ASKES dan PP No. 69 Tahun 1991. Jaminan hari tua dan pensiun bagi PNS melalui PT TASPEN dilandasi dengan UU No. 43 Tahun 1999 tentang Perubahan Atas Undang-Undang No. 8 Tahun 1974 tentang Pokok-Pokok Kepegawaian. Bagi TNI/Polri melalui PT ASABRI dilandasi dengan UU No. 6 Tahun 1966. Dengan adanya produk-produk hukum yang bervariasi tersebut, mengakibatkan banyaknya lembaga yang melaksanakan perlindungan dan jaminan sosial. Hal ini berlawanan dengan hukum bilangan besar (law of the large number), yaitu dengan cakupan besar (peserta), maka sebaran risiko (risk distribution) akan lebih merata dan beban yang dipikul masing-masing peserta (premi) makin kecil.

Selanjutnya, dengan Putusan Mahkamah Konstitusi (MK) dalam Perkara No.07/PUU-III/2005 mengenai pengujian UU No. 40 Tahun 2004 tentang Sistem Jaminan Sosial Nasional (SJSN) terhadap UUD 1945 dinyatakan bahwa Pasal 5 ayat (2), (3), dan (4) UU No. 40 Tahun 2004 tentang Sistem Jaminan Sosial Nasional bertentangan dengan UUD Negara Republik Indonesia Tahun 1945. Sehingga Pasal 5 ayat (2), (3), dan (4) UU No. 40 Tahun 2004 tersebut tidak mempunyai kekuatan hukum mengikat. Pasal 5 ayat (2) berbunyi "sejak diberlakukannya Undang-Undang ini, penyelenggara jaminan sosial yang ada dinyatakan sebagai Badan Penyelenggara Jaminan Sosial menurut Undang-Undang ini."

Pasal 5 ayat (2) tersebut mengandung maksud pada saat diundangkan UU SJSN ini bila ada badan atau lembaga yang telah menyelenggarakan jaminan sosial, maka langsung dinyatakan sebagai Badan Penyelenggara Jaminan Sosial (BPJS). Tetapi UU SJSN tidak secara tegas mengemukakan badan atau lembaga mana yang telah menyelenggarakan jaminan sosial dimaksud. Pasal 5 ayat (3), berbunyi “Badan Penyelenggara Jaminan Sosial sebagaimana dimaksud ayat (1) adalah a. Perusahaan Perseroan (Persero) Jaminan Sosial Tenaga Kerja (JAMSOSTEK), b. Perusahaan Perseroan (Persero) Dana Tabungan dan Asuransi pegawai Negeri (TASPEN), c. Perusahaan Perseroan (Persero) Asuransi Sosial Angkatan Bersenjata Republik Indonesia (ASABRI), dan d. Perusahaan Perseroan (Persero) Asuransi Kesehatan Indonesia (ASKES)." 
Pasal 5 ayat (3) tersebut secara jelas menunjuk ayat (1) yang berbunyi "Badan Penyelenggara Jaminan Sosial harus dibentuk dengan Undang-Undang." Bunyi ayat (3) yang menunjuk ayat (1) ini memberikan pengertian seakan-akan JAMSOSTEK, TASPEN, ASABRI dan ASKES adalah BPJS, sehingga harus dibentuk dengan undang-undang. Padahal, berdasarkan UU No. 19 Tahun 2003 tentang BUMN dan PP No. 12 Tahun 1998 tentang Perusahaan Perseroan, JAMSOSTEK, TASPEN, ASABRI dan ASKES adalah BUMN yang berbentuk perseroan yang didirikan dengan Peraturan Pemerintah, bukan Undang-Undang.

Pasal 52 ayat (2) yang berbunyi "Semua ketentuan yang mengatur mengenai Badan Penyelenggara Jaminan Sosial sebagaimana dimaksud pada ayat (1) disesuaikan dengan Undang-Undang ini paling lambat 5 (lima) tahun sejak UndangUndang ini diundangkan. Jadi, badan atau lembaga mana yang sebenarnya dianggap telah menyelenggarakan jaminan sosial sebagaimana yang dimaksud dalam UU SJSN dan apa dampak putusan MK yang tidak memberlakukan Pasal 5 ayat (2), (3) dan (4). Atau apa makna tetap diberlakukannya Pasal 5 ayat (1), dan Pasal 52 ayat (2) yang berbunyi "Semua ketentuan yang mengatur mengenai Badan Penyelenggara Jaminan Sosial sebagaimana dimaksud pada ayat (1) disesuaikan dengan Undang-Undang ini paling lambat 5 (lima) tahun sejak Undang-Undang ini diundangkan.

Begitu pula, bagaimana nasib JAMSOSTEK, TASPEN, ASABRI dan ASKES, karena keempat BUMN ini tidak bisa langsung menyesuaikan diri dengan UU SJSN ini berdasarkan Pasal 52 ayat (2), karena Pasal 5 ayat (2) dan (3) telah dinyatakan tidak mempunyai kekuatan hukum mengikat alias tidak berlaku. Berdasarkan uraian di atas, menunjukkan bahwa bahasan tentang implementasi SJSN saat ini merupakan bahasan yang menarik dan penting untuk dikaji secara lebih mendalam.

\section{Rumusan Masalah}

Dalam penelitian ini rumusan masalahnya, bagaimana pelaksanaan Undang-Undang Nomor 40 Tahun 2004 tentang Sistem Jaminan Sosial Nasional terkait Jaminan Sosial Kesehatan pasca Putusan Mahkamah Konstitusi No. 
07/PUU-III/2005 tentang Pengujian UU No. 40 Tahun 2004 tentang Sistem Jaminan Sosial Nasional (SJSN) terhadap UUD 1945?

\section{Tujuan Penelitian}

Penelitian ini bertujuan memahami dan menganalisis pelaksanaan Undang-Undang Nomor 40 Tahun 2004 tentang Sistem Jaminan Sosial Nasional terkait Jaminan Sosial Kesehatan pasca Putusan Perkara No. 07/PUU-III/2005 tentang Pengujian UU No. 40 Tahun 2004 tentang Sistem Jaminan Sosial Nasional (SJSN) terhadap UUD 1945.

\section{Metode Penelitian}

Penelitian ini termasuk library research, yang objek utamanya adalah bukubuku atau sumber kepustakaan lain (literatur) yaitu jurnal, catatan, maupun laporan hasil penelitian dari penelitian terdahulu. Data dicari dan ditemukan melalui kajian pustaka yang relevan dengan pembahasan. Penelitian ini termasuk kategori penelitian kualitatif dengan prosedur kegiatan dan teknik penyajian finalnya secara deskriptif. ${ }^{8}$ Dengan mengutip pendapat dari Denzin dan Lincoln yang menjelaskan bahwa penelitian kualitatif adalah penelitian yang menggunakan latar ilmiah, dengan maksud menafsirkan fenomena yang terjadi dan dilakukan dengan jalan melibatkan berbagai metode yang ada. ${ }^{9}$

Telaah yang dilaksanakan adalah untuk memecahkan permasalahan, yang pada dasarnya tertumpu pada penelaahan kritis dan mendalam terhadap bahanbahan pustaka yang relevan. Karena penelitian ini merupakan library research, metode pengumpulan data yang digunakan berupa bahan-bahan pustaka yang berkesinambungan (koheren) dengan objek pembahasan yang diteliti. ${ }^{10}$ Sumber data diperoleh melalui library research yaitu dengan menelusuri buku-buku atau

8 John W. Creswell,Researh Design. Quanlitative \& Quantitative Approaches, Sage Publication, Inc. New York, 2002, hlm. 34.

${ }^{9}$ Lexy J. Moleong, Metodologi Penelitian Kualitatif, Remaja Rosdakarya, Bandung, 2005, hlm. 5. hlm.12.

${ }^{10}$ M. Iqbal Hassan, Pokok-Pokok Materi Metodologi Penelitian, Penerbit Ghalia Indonesia, Jakarta, 2002, 
tulisan-tulisan tentang efektifitas kelembagaan SJSN serta buku-buku lain yang mendukung pendalaman dan ketajaman analisis.

Dalam metode pengumpulan data, peneliti melakukan identifikasi wacana dari berbagai buku atau artikel, majalah, jurnal, web (internet) atau pun informasi lainnya yang berkaitan dengan substansi penelitian untuk mencari keterkaitan dengan variabel berupa catatan, transkrip, surat kabar, dan majalah/jurnal. Untuk itu dilakukan langkah-langkah sebagai berikut: a) editing, yaitu pemeriksaan kembali dari data yang diperoleh terutama dari segi kelengkapan, kejelasan makna dan koherensi makna antara yang satu dengan yang lain; b) organizing yakni menyusun data yang diperoleh dengan kerangka yang sudah ditentukan; c) penemuan hasil penelitian, yakni melakukan analisis lanjutan terhadap hasil penyusunan data dengan menggunakan kaidah-kaidah, teori dan metode yang telah ditentukan sehingga diperoleh kesimpulan (inferensi) tertentu yang merupakan hasil jawaban dari rumusan masalah. ${ }^{11}$

Analisis data merupakan bagian yang terpenting dalam metode ilmiah, karena dengan analisislah data tersebut dapat bermakna dalam memecahkan masalah penelitian. ${ }^{12}$ Analisis data kualitatif yang digunakan dalam penelitian ini berupa kata-kata bukan berupa angka-angka yang disusun dalam tema yang luas. Jadi, penelitian ini menggunakan metode analisis isi (content analysis). Analisis isi adalah suatu teknik penelitian untuk membuat kesimpulan-kesimpulan (inferensi) yang dapat ditiru (replicabel) dan dengan data yang valid, dengan memperhatikan konteksnya. ${ }^{13}$

\section{Hasil Penelitian dan Pembahasan}

\section{Jaminan Sosial Bidang Kesehatan}

Berdasarkan Keputusan Sidang Tahunan MPR RI 2001 menugaskan Presiden untuk membentuk Sistem Jaminan Sosial Nasional dalam rangka memberikan perlindungan sosial yang lebih menyeluruh dan terpadu.

${ }^{11} \mathrm{Ibid}, \mathrm{hlm} .13$.

12 Garna, Judistira K., Metode Penelitian Sosial: Penelitian Dalam Ilmu Pemerintahan, I. Desain dan Rencana Penelitian, Primaco Akademika, Bandung, 2000, hlm. 21.

13 Sugiyono, Metode Penelitian Bisnis, Penerbit Alfabeta, Bandung, 2012, hlm. 373. 
Selanjutnya, Presiden mengambil inisiatif menyusun Rancangan Undang-Undang Jaminan Sosial Nasional. Melalui Tap MPR, Pasal 34 ayat (1) menyatakan bahwa fakir miskin dan anak terlantar dipelihara oleh negara. Melalui perubahan keempat UUD 1945 tanggal 10 Agustus 2002, dilakukan pengubahan dan/atau penambahan pada Pasal 34 ayat (2), tercantum bahwa negara mengembangkan sistem jaminan sosial bagi seluruh rakyat dan memberdayakan masyarakat yang lemah dan tidak mampu sesuai dengan martabat kemanusiaan. ${ }^{14}$

Kebijakan tentang pengembangan sistem perlindungan sosial harus didasari pada peraturan perundangan yang jelas dan memudahkan semua pihak memahami sistem tersebut. Sebuah Undang-Undang UU No. 40 Tahun 2004 tentang Sistem Jaminan Sosial Nasional telah dihasilkan dan memuat skema sistem jaminan sosial formal terpadu dan terkoordinasi.

Dalam UU tersebut dinyatakan bahwa yang dimaksud jaminan sosial adalah salah satu bentuk perlindungan sosial untuk menjamin seluruh rakyat agar dapat memenuhi kebutuhan dasar hidupnya yang layak. Bantuan iuran adalah iuran yang dibayar oleh Pemerintah bagi fakir miskin dan orang tidak mampu sebagai peserta program jaminan sosial. Salah satu ciri menonjol dari UU SJSN tersebut adalah kepesertaannya yang bersifat wajib bagi seluruh penduduk dan adanya subsidi (bantuan) iuran bagi penduduk miskin dan kurang mampu (rentan). Dengan ketentuan itu,maka penduduk miskin tetap memperoleh jaminan sosial meskipun mereka tidak mampu membayar iuran sebab iuran bagi penduduk miskin disubsidi oleh pemerintah. Pada tahap awal bantuan iuran yang diberikan pemerintah kepada penduduk miskin masih terbatas pada jaminan kesehatan.

Oleh karena itu, sebuah perlindungan sosial lain yang memungkinkan penduduk rentan berproduksi dan tercegah dari kemiskinan, bantuan sosial atau pemberdayaan lain, baik oleh sektor lain dari pemerintah pusat, pemerintah daerah, maupun masyarakat, harus diupayakan. Yang penting adalah juga harus dicegah terjadinya duplikasi program perlindungan sosial kepada penduduk yang sama. Dengan penduduk miskin memperoleh jaminan pelayanan, maka subsidi bantuan sosial pemerintah kepada penduduk miskin harus diarahkan

14 Amandemen Undang-Undang Dasar Negara Republik Indonesia Tahun 1945. 
untuk program lain yang menjamin kecukupan kebutuhan gizi dan kemampuan bekerja produktif.

Kesehatan yang baik dan prima memungkinkan seseorang hidup lebih produktif baik secara sosial maupun ekonomi. Oleh karena itu, kesehatan menjadi salah satu hak dan kebutuhan dasar yang harus dipenuhi, agar setiap individu dapat berkarya dan menikmati kehidupan yang bermartabat. Saat ini jasa pelayanan kesehatan makin lama makin mahal. Tingginya biaya kesehatan yang harus dikeluarkan oleh perseorangan, menyebabkan tidak semua anggota masyarakat mampu untuk memperoleh pelayanan kesehatan yang layak. Selain itu, kemampuan pemerintah untuk mensubsidi pelayanan kesehatan sangat rendah. Tanpa sistem yang menjamin pembiayaan kesehatan, maka akan semakin banyak masyarakat yang tidak mampu yang tidak memperoleh pelayanan kesehatan sebagaimana yang mereka butuhkan.Dengan kecenderungan meningkatnya biaya hidup, termasuk biaya pemeliharaan kesehatan, diperkirakan beban masyarakat terutama penduduk berpenghasilan rendah akan bertambah berat. Biaya kesehatan yang meningkat akan menyulitkan akses masyarakat terhadap pelayanan kesehatan yang dibutuhkannya, terutama bila pembiayaannya harus ditanggung sendiri (out of pocket) dalam sistem fee for services.

Sistem fee for service untuk sistem pelayanan kesehatan menyebabkan masyarakat sulit menjangkau pelayanan kesehatan yang layak. Namun, apabila hendak ikut asuransi, tidak banyak masyarakat yang mampu membayar biaya premi. Sebagai contoh, pada 1995, biaya rawat inap pasien di rumah sakit selama lima hari menghabiskan 1,4 kali rata-rata pendapatan sebulan penduduk DKI Jakarta. 1998 biaya ini melonjak menjadi 2,7 kali. Apabila biaya tersebut tidak ditanggung oleh kantor atau asuransi, berarti biaya rumah tangga orang yang bersangkutan akan tersedot untuk membayar perawatan di rumah sakit.

\section{Analisis Undang-Undang No. 40 Tahun 2004 (Pasca Putusan Perkara No. 07/PUU-III/2005)}

Putusan MK Perkara No. 07/PUU-III/2005, Pemohon mengajukan permohonan pengujian Undang-Undang (UU) Republik Indonesia No. 40 Tahun 2004 Pasal 5 ayat (1), ayat (3), dan ayat (4) dan Pasal 52 tentang Sistem Jaminan 
Sosial Nasional (SJSN) terhadap UUD Negara Republik Indonesia Tahun 1945.15 Tuntutan Pemohon dalam Perkara No. 07/PUU-III/2005 tersebut adalah sebagai berikut. Pemohon I mengajukan permohonan pengujian UU SJSN yang menganggap kewenangan untuk mengatur jaminan sosial, sesuai dengan otonomi seluas-luasnya yang diberikan oleh UUD 1945 khususnya Pasal 18 ayat (2) dan (5) adalah kewenangan Daerah, sebagaimana dinyatakan dalam ketentuan UU No. 32 Tahun 2004 tentang Pemerintahan Daerah (UU Pemda) khususnya ketentuan Pasal 40 UU Pemda, DPRD merupakan lembaga perwakilan rakyat daerah dan berkedudukan sebagai unsur penyelenggaraan pemerintahan daerah.

Pemohon II, dalam permohonannya mendalilkan dirinya sebagai badan hukum telah dirugikan hak/kewenangan konstitusionalnya untuk menjalankan tugas dan tanggung jawab Satuan Pelaksana Jaminan Pemeliharaan Kesehatan Masyarakat (SATPEL JPKM) dalam rangka menyelenggarakan, mengkoordinasikan, dan mengembangkan program JPKM sebagaimana diatur dalam Perda No. 08 Tahun 2003 oleh berlakunya Pasal 5 ayat (1), (3), dan (4) UU SJSN karena tidak memperoleh kesempatan yang sama dalam pemerintahan dan tidak mendapatkan hak atas pengakuan, jaminan, perlindungan, dan kepastian hukum yang adil dan perlakuan yang sama di hadapan hukum, serta mendapat perlakuan yang bersifat diskriminatif, dan tidak mendapatkan perlindungan atas perlakuan yang bersifat diskriminatif itu dari Pemerintah Pusat c.q. Departemen Kesehatan. Menurut anggapan Pemohon III, tidak memperoleh kesempatan yang sama dalam pemerintahan dan tidak mendapatkan hak atas pengakuan, jaminan, perlindungan, dan kepastian hukum yang adil dan perlakuan yang sama di hadapan hukum, serta mendapat perlakuan yang bersifat diskriminatif dan tidak mendapatkan perlindungan dari Pemerintah c.q. Departemen Kesehatan.

Atas dasar permohonan tersebut, Mahkamah berpendapat, sepanjang menyangkut sistem jaminan sosial yang dipilih, UU SJSN telah cukup memenuhi maksud Pasal 34 ayat (2) UUD 1945, yakni bahwa sistem yang dipilih itu mencakup seluruh rakyat dengan maksud untuk meningkatkan keberdayaan masyarakat yang lemah dan tidak mampu sesuai dengan martabat kemanusiaan. Oleh karena sistem jaminan sosial yang dipilih, menurut pendapat Mahkamah, 
telah memenuhi maksud Pasal 34 ayat (2) UUD 1945, maka berarti UU SJSN dengan sendirinya juga merupakan penegasan kewajiban negara terhadap hak atas jaminan sosial sebagai bagian dari hak asasi manusia, sebagaimana dimaksud Pasal 28H ayat (3) UUD 1945, yang mewajibkan negara untuk menghormati (to respect), melindungi (to protect), dan menjamin pemenuhannya (to fulfil). Sepanjang menyangkut sistem yang dipilih, UU SJSN telah memenuhi ketentuan Pasal 34 ayat (2) UUD 1945.

Berdasarkan pertimbangan-pertimbangan di atas, meskipun Mahkamah berpendapat bahwa UU SJSN telah cukup memenuhi maksud Pasal 34 ayat (2) UUD 1945, dalam arti bahwa sistem jaminan sosial yang dipilih UU SJSN telah cukup menjabarkan maksud Undang-Undang Dasar yang menghendaki agar sistem jaminan sosial yang dikembangkan mencakup seluruh rakyat dan bertujuan untuk meningkatkan keberdayaan masyarakat yang lemah dan tidak mampu sesuai dengan martabat kemanusiaan, namun Mahkamah tidak sependapat dengan pendirian Pemerintah maupun Dewan Perwakilan Rakyat yang secara eksklusif merupakan kewenangan Pemerintah (Pusat), sebagaimana tercermin dari ketentuan dalam Pasal 5, khususnya ayat (4), UU SJSN. Sebab, jika diartikan demikian, hal itu akan bertentangan dengan makna pengertian negara yang di dalamnya mencakup Pemerintah (Pusat) maupun Pemerintahan Daerah sebagaimana dimaksud oleh Pasal 18 ayat (5) UUD 1945,16 yang kemudian dijabarkan dalam UU Pemda.

Atas dasar Pasal 22 huruf h UU Pemda, Pemerintahan Daerah mempunyai kewajiban untuk pemohon yang mendalilkan kewenangan untuk mengembangkan sistem jaminan sosial secara eksklusif merupakan kewenangan Daerah dengan argumentasi bahwa sesuai dengan ajaran otonomi yang seluasluasnya, yang menurut Pemohon sesuai dengan Pasal 18 ayat (5) UUD 1945 sebagaimana dijabarkan lebih lanjut dalam UU Pemda khususnya Pasal 22 dan Pasal 167 ayat (1) dan (2), maka sepanjang suatu urusan oleh Undang-Undang tidak ditentukan sebagai urusan atau kewenangan Pemerintah (Pusat), maka hal itu merupakan urusan atau kewenangan Daerah.

${ }^{16}$ HAW Widjaya, Penyelenggaraan Otonomi di Indonesia dalam Rangka Sosialisasi UU No. 32 Tabun 2004 tentang Pemerintahan Daerah, RajaGrafindo Persada, Jakarta, 2005, hlm. 53. 
Mahkamah tidak sependapat dengan dalil Pemohon tersebut, sebab jika jalan pikiran demikian diikuti, maka di satu pihak, besar kemungkinan terjadi keadaan hanya daerah-daerah tertentu saja yang mampu menyelenggarakan sistem jaminan sosial dan itu pun tidak menjamin bahwa jaminan sosial yang diberikan tersebut cukup memenuhi standar kebutuhan hidup yang layak antara daerah yang satu dengan daerah yang lain, serta di lain pihak, jika karena alasan tertentu seseorang terpaksa harus pindah ke lain daerah, tidak terdapat jaminan akan kelanjutan penikmatan hak atas jaminan sosial orang yang bersangkutan setelah berada di daerah lain. Keadaan demikian akan bertentangan dengan maksud Pasal 34 ayat (2) UUD 1945 yang menghendaki hak atas jaminan sosial itu harus dapat dinikmati oleh setiap orang atau seluruh rakyat.

Sejalan dengan pendapat Mahkamah, bahwa pengembangan sistem jaminan sosial adalah bagian dari pelaksanaan fungsi pelayanan sosial negara yang kewenangan untuk menyelenggarakannya berada di tangan pemegang kekuasaan pemerintahan negara, di mana kewajiban pelaksanaan sistem jaminan sosial tersebut, sesuai dengan Pasal 18 ayat (5) UUD 1945 sebagaimana dijabarkan lebih lanjut dalam UU Pemda khususnya Pasal 22 huruf h, bukan hanya menjadi kewenangan Pemerintah Pusat tetapi dapat juga menjadi kewenangan Pemerintahan Daerah, maka UU SJSN tidak boleh menutup peluang Pemerintahan Daerah untuk ikut juga mengembangkan sistem jaminan sosial.

Tertutupnya peluang Pemerintahan Daerah untuk ikut mengembangkan sistem jaminan sosial dikarenakan adanya ketentuan dalam Pasal 5 UU SJSN yang berbunyi: (1) Badan Penyelenggara Jaminan Sosial harus dibentuk dengan UndangUndang;17 (2) Sejak berlakunya undang-undang ini, badan penyelenggara jaminan sosial yang ada dinyatakan sebagai Badan Penyelenggara Jaminan Sosial menurut Undang-Undang ini; (3) Badan Penyelenggara Jaminan Sosial sebagaimana dimaksud pada ayat (1) adalah: a. Perusahaan Perseroan (Persero) Jaminan Sosial Tenaga Kerja (Jamsostek); b. Perusahaan Perseroan (Persero) Dana Tabungan dan Asuransi Pegawai Negeri (Taspen); c. Perusahaan Perseroan (Persero) Asuransi Sosial Angkatan Bersenjata Republik Indonesia (Asabri); d. Perusahaan Perseroan (Persero) Asuransi Kesehatan Indonesia (Askes); (4) Dalam hal diperlukan Badan 
Penyelenggara Jaminan Sosial selain dimaksud pada ayat (3), dapat dibentuk yang baru dengan Undang-Undang. ${ }^{18}$

Berdasarkan ketentuan Pasal 5 UU SJSN di atas, tampak bahwa, di satu pihak, perumusan Pasal 5 di atas menutup peluang Pemerintahan Daerah untuk ikut mengembangkan suatu sub-sistem jaminan sosial dalam kerangka sistem jaminan sosial nasional sesuai dengan kewenangan yang diturunkan dari ketentuan Pasal 18 ayat (2) dan (5) UUD 1945. Di pihak lain, dalam ketentuan Pasal 5 itu sendiri terdapat rumusan yang saling bertentangan serta sangat berpeluang menimbulkan multi-interpretasi yang bermuara pada ketidakpastian hukum (rechtsonzekerheid) yang oleh karena itu bertentangan dengan Pasal 28D ayat (1) UUD 1945.

Dikatakan menutup peluang Pemerintahan Daerah oleh karena dengan adanya Pasal 5 ayat (4) dan kaitannya dengan Pasal 5 ayat (1) UU SJSN tidak memungkinkan bagi Pemerintahan Daerah untuk membentuk badan penyelenggara jaminan sosial tingkat daerah. Padahal, sebagaimana telah diuraikan dalam pertimbangan di atas, Pemerintahan Daerah justru diwajibkan untuk mengembangkan sistem jaminan sosial. Oleh karena itu, Pasal 5 ayat (1) UU SJSN harus ditafsirkan bahwa ketentuan tersebut adalah dimaksudkan untuk pembentukan badan penyelenggara tingkat nasional yang berada di pusat, sedangkan untuk pembentukan badan penyelenggara jaminan sosial tingkat daerah dapat dibentuk dengan peraturan daerah dengan memenuhi ketentuan tentang sistem jaminan sosial nasional sebagaimana diatur dalam UU SJSN. ${ }^{19}$

Rumusan yang saling bertentangan serta berpeluang menimbulkan ketidakpastian hukum (rechtsonzekerheid) karena pada ayat (1) dinyatakan bahwa Badan Penyelenggara Jaminan Sosial harus dibentuk dengan Undang-Undang, sementara pada ayat (3) dikatakan bahwa Persero Jamsostek, Persero Taspen, Persero Asabri, dan Persero Askes adalah Badan Penyelenggara Jaminan Sosial sebagaimana dimaksud pada ayat (1), padahal tidak semua badan-badan tersebut dibentuk dengan Undang-Undang. Seandainya pembentuk Undang-Undang

\footnotetext{
${ }^{18}$ Soekamto, dkk, Reformasi Sistem Jaminan Sosial di Indonesia, Social Health Insurance Project Indonesia, 2006, hlm. 67.

19 Yuliandri, Asas-Asas Pembentukan Peraturan Perundang-undangan yang Baik, Cetakan Pertama, PT RajaGrafindo Persada, Jakarta, 2009, hlm. 73
} 
bermaksud menyatakan bahwa selama belum terbentuknya Badan Penyelenggara Jaminan Sosial sebagaimana dimaksud pada ayat (1), badan-badan sebagaimana disebutkan pada ayat (3) di atas diberi hak untuk bertindak sebagai badan penyelenggara jaminan sosial, maka hal itu sudah cukup tertampung dalam Ketentuan Peralihan pada Pasal 52 UU SJSN.

Ketentuan dalam Pasal 5 ayat (4), makin memperkuat kesimpulan bahwa pembentuk Undang-Undang memang bermaksud menyatakan, badan penyelenggara jaminan sosial harus dibentuk dengan Undang-Undang tersendiri. Kemungkinan tafsir lainnya adalah, dengan rumusan dalam Pasal 5 ayat (2) dan (3) UU SJSN di atas, maka tidak ada lagi kebutuhan untuk memenuhi ketentuan Pasal 5 ayat (1), sebab badan-badan sebagaimana yang disebut pada ayat (2) dan (3) itulah yang dimaksud oleh ayat (1) dan pada saat yang sama sesungguhnya tidak ada kebutuhan bagi adanya rumusan sebagaimana tertuang dalam ayat (4). Oleh karena itu, dengan menghubungkan ketentuan ayat (1), (2), (3), dan (4) dari Pasal 5 UU SJSN tersebut, ${ }^{20}$ tidak dapat ditarik kesimpulan lain kecuali bahwa memang kehendak pembentuk undang-undang untuk menyatakan bahwa Jamsostek, Taspen, Asabri, dan Askes sajalah yang merupakan badan penyelenggara jaminan sosial sebagaimana dimaksud pada ayat (1) serta tidak mungkin lagi membentuk badan penyelenggara jaminan sosial lain di luar itu. Kesimpulan demikian juga tercermin dari keterangan Pemerintah, keterangan DPR, maupun keterangan para ahli yang diajukan Pemerintah sebagaimana yang telah diuraikan di atas.Oleh karena di satu pihak, ternyata Pasal 5 ayat (1), (2), (3), dan (4) UU SJSN saling berkait akibatnya daerah menjadi tidak mempunyai peluang untuk mengembangkan sistem jaminan sosial dan membentuk badan penyelenggara sosial.

Terhadap Pasal 52 UU SJSN yang juga dimohonkan pengujian oleh Pemohon, Mahkamah berpendapat bahwa ketentuan Pasal 52 UU SJSN tersebut justru dibutuhkan untuk mengisi kekosongan hukum (rechtsvacuum) dan menjamin kepastian hukum (rechtszekerheid) karena belum adanya badan penyelenggara jaminan sosial yang memenuhi persyaratan agar UU SJSN dapat dilaksanakan. Dengan demikian, permohonan Pemohon sepanjang menyangkut 
Pasal 52 UU SJSN, tidak cukup beralasan. Selanjutnya, Mahkamah berpendapat permohonan Pemohon dapat dikabulkan untuk sebagian yaitu Pasal 5 ayat (3), yang berbunyi "Badan Penyelenggara Jaminan Sosial sebagaimana dimaksud pada ayat (1) adalah a. Perusahaan Perseroan (Persero) Jaminan Sosial Tenaga Kerja (Jamsostek); b. Perusahaan Perseroan (Persero) Dana Tabungan dan Asuransi Pegawai Negeri (Taspen); c. Perusahaan Perseroan (Persero) Asuransi Sosial Angkatan Bersenjata Republik Indonesia (Asabri); d. Perusahaan Perseroan (Persero) Asuransi Kesehatan Indonesia (Askes)".

Hal tersebut dikarenakan materi yang terkandung di dalamnya telah tertampung dalam Pasal 52 yang apabila dipertahankan keberadaannya akan menimbulkan multitafsir dan ketidakpastian hukum. Selanjutnya, Pasal 5 ayat (2) yang berbunyi "Sejak berlakunya Undang-Undang ini, badan penyelenggara jaminan sosial yang ada dinyatakan sebagai Badan Penyelenggara Jaminan Sosial menurut Undang-Undang ini" karena walaupun tidak dimohonkan dalam petitum namun ayat ini merupakan satu kesatuan yang tidak dapat dipisahkan dari ayat (3) sehingga jika dipertahankan juga akan menimbulkan multitafsir dan ketidakpastian hukum sebagaimana Pasal 5 ayat (3).

Pasal 5 ayat (4) yang berbunyi "Dalam hal diperlukan Badan Penyelenggara Jaminan Sosial selain dimaksud pada ayat (3), dapat dibentuk yang baru dengan Undang-Undang" karena ternyata menutup peluang bagi Pemerintahan Daerah untuk membentuk dan mengembangkan badan penyelenggara jaminan sosial tingkat daerah dalam kerangka sistem jaminan sosial nasional.Pasal 5 ayat (1) yang berbunyi "Badan Penyelenggara Jaminan Sosial harus dibentuk dengan UndangUndang"tidak bertentangan dengan UUD 1945 asalkan ditafsirkan bahwa yang dimaksud oleh ketentuan tersebut adalah pembentukan badan penyelenggara jaminansosial tingkat nasional yang berada di Pusat. Dengan demikian permohonan Pemohon sepanjang mengenai Pasal 5 ayat (1), sebagaimana halnya Pasal 52 UU SJSN, juga tidak cukup beralasan.

Mengingat Pasal 56 ayat (2) dan (5) serta Pasal 57 ayat (1) dan (3) UU No. 24 Tahun 2003 tentang Mahkamah Konstitusi; “Mengadili” Mengabulkan permohonan Pemohon untuk sebagian; Menyatakan Pasal 5 ayat (2), (3), dan (4) UU No. 40 Tahun 2004 tentang Sistem Jaminan Sosial Nasional (Lembaran Negara 
Republik Indonesia Tahun 2004 Nomor 150, Tambahan Lembaran Negara Republik Indonesia Nomor 4456) bertentangan dengan Undang-Undang Dasar Negara Republik Indonesia Tahun 1945. Menyatakan Pasal 5 ayat (2), (3), dan (4) UU No. 40 Tahun 2004 tentang Sistem Jaminan Sosial Nasional (Lembaran Negara Republik Indonesia Tahun 2004 Nomor 150, Tambahan Lembaran Negara Republik Indonesia Nomor 4456) tidak mempunyai kekuatan hukum mengikat; Menolak permohonan Pemohon selebihnya.

Berdasarkan Putusan No. 07/PUU-III/2005 Mahkamah Konstitusi dengan pertimbangan tersebut, adalah sudah tepat dan adil karena UU No. 40 Tahun 2004 tentang Sistem Jaminan Sosial Nasional, khususnya Pasal 5 ayat (2) dan ayat (3) UU SJSN adalah tidak diskriminatif, dan tidak membatasi kewenangan pemerintah daerah, apalagi mengebiri dan menghancurkan Badan Pelaksana Jaminan Pemeliharaan Kesehatan Masyarakat (Bapel JPKM) dan Satpel Satuan Pelaksana Jaminan Pemeliharaan Kesehatan Masyarakat (yang kemudian disingkat sebagai (Satpel JPKM). Bahwa UU SJSN bertujuan untuk memberbaiki sistem badan penyelenggara yang ada, memperbaiki jaminan dan sistem penyelenggaraan program jaminan sosial, dan memperluas cakupan program jaminan sosial kepada seluruh rakyat sesuai dengan amanat Pasal 34 ayat (2) UUD Tahun 1945.

Kelembagaan pengelola dan penyelenggara perlindungan sosial secara garis besar dipilah menjadi dua, yaitu kelembagaan yang menangani jaminan sosial dan kelembagaan yang menangani bantuan sosial lain. Dalam UU No. 40 Tahun 2004 tentang Sistem Jaminan Sosial Nasional, lembaga yang menangani jaminan sosial disebut sebagai Badan Penyelenggara Jaminan Sosial (BPJS). Selama ini sudah ada empat BPJS yang dikenali dan disebutkan dalam UU SJSN, yang penyelenggaraannya harus menyesuaikan diri dengan UU SJSN. Selain empat BPJS tersebut, dapat dibentuk BPJS baru dengan UU.

Pasal 5 ayat (1) UU tersebut menyatakan bahwa Badan Penyelenggara Jaminan Sosial (baru) harus dibentuk dengan Undang-Undang. Semula Pasal 5 ayat (3) menyatakan bahwa yang dimaksud BPJS dalam Undang-Undang ini adalah PT Jamsostek (Persero), PT Taspen (Persero), PT ASABRI (Persero) dan PT Askes (Persero). Namun pada tanggal 18 Agustus 2005 lalu, Rapat Permusyawaratan 
Hakim Konstitusi telah memutus perkara No. 07/PUU-III/2005 mengenai pengujian UU No. 40 Tahun 2004 tentang Sistem Jaminan Sosial Nasional (SJSN) terhadap UUD 1945, yang diajukan oleh DPRD Provinsi Jawa Timur dkk.

Putusan yang dibacakan pada 31 Agustus 2005, menyatakan bahwa Pasal 5 ayat (2), (3) dan (4) UU SJSN bertentangan dengan UUD 1945, dan tidak mempunyai kekuatan hukum mengikat. Jadi, dalam judicial review tersebut, Mahkamah Konstitusi menyatakan bahwa pasal tersebut tidak mengikat dan penetapan empat badan penyelenggara untuk program jaminan sosial nasional sudah cukup diatur oleh Pasal 52 UU SJSN. Esensinya, bahwa ke empat BPJS yang telah ada sah dan sesuai dengan amanat konstitusi.

\section{Pelaksanaan UU No. 40 Tahun 2004 Pasca Putusan MKNo.07/PUU-III/2005}

Hingga saat ini, terdapat peraturan pelaksanaan UU BPJS yang sudah ditetapkan yaitu Perpres Nomor 12 Tahun 2013 tentang Jaminan Kesehatan tanggal 18 Januari 2013. Berdasarkan UU BPJS, BPJS dibentuk sebagai badan hukum publik yang bertanggung jawab kepada Presiden. BPJS yang dibentuk di antaranya adalah BPJS Kesehatan yang mulai beroperasi 1 Januari 2014. Pada 1 Januari 2014 PT Askes (Persero) dinyatakan bubar tanpa likuidasi. Pelaksanaan transformasi Persero menjadi BPJS, derajat transformasi tersebut tidak tegas, perubahan PT Askes jadi BPJS Kesehatan (status perundang-undangan yang mengatur PT Askes tidak tegas dicabut).

Mulai 1 Januari 2014 terjadi dualisme organisasi penyelenggaraan jaminan sosial yaitu BPJS untuk program jaminan kesehatan (BPJS Kesehatan) dan program kecelakaan kerja, jaminan hari tua, jaminan pensiun dan jaminan kematian (BPJS Ketenagakerjaan). Hubungan BPJS dengan DJSN melalui 4 media yaitu keputusan DJSN, usulan DJSN, hasil pengawasan/monev, dan tembusan laporan BPJS kepada Presiden. Komunikasi BPJS dengan Presiden melalui 2 jalur,

yaitu 1. Presiden sebagai Kepala Pemerintahan melalui regulasi dan laporan pertanggungjawaban BPJS. 2. Presiden sebagai Kepala Administrasi Negara; melalui Keputusan Presiden: a. penetapan anggota Dewas dan Direksi; b. 
pengangkatan Pansel; c. pengenaan sanksi administratif; 4. pemindahtanganan aset BPJS senilai 100.000.000.000,00 - 500.000.000.000,00.

Jadi, program Jaminan Kesehatan Nasional yang pelaksanaannya dipercayakan pada BPJS Kesehatan masih jauh dari makna keadilan. Penerapan BPJS Kesehatan masih memiliki persoalan dalam banyak hal. Pertama, persoalan BPJS Kesehatan sudah muncul sejak proses aktivasi kartu. BPJS menerapkan aturan bahwa kartu pengguna BPJS baru bisa aktif sepekan setelah pendaftaran diterima. Padahal sakit menimpa tanpa terduga dan tak mungkin bisa ditunda. Kedua, rujukan lembaga jasa kesehatan yang ditunjuk BPJS Kesehatan juga terbatas dan tidak fleksibel. Peserta BPJS hanya boleh memilih satu fasilitas kesehatan untuk memperoleh rujukan dan tak bisa ke faskes lain meski samasama bekerja sama dengan BPJS. Keterbatasan itu, menyulitkan orang yang sering bepergian dan bekerja di tempat jauh. Ketiga, adalah rumitnya alur pelayanan BPJS Kesehatan karena menerapkan alur pelayanan berjenjang. Sebelum ke rumah sakit, peserta wajib terlebih dulu ke faskes tingkat pertama, yaitu puskesmas. Keempat, banyak peserta BPJS mengeluhkan pembayaran biaya pengobatan yang tak ditanggung sepenuhnya oleh BPJS. Sesuai dengan Pasal 2 UU No. 24 Tahun 2011, BPJS seharusnya menyelenggarakan sistem jaminan sosial berdasar asas kemanusiaan, manfaat, dan keadilan sosial bagi semua rakyat Indonesia.Begitu pula dengan Permenkes No. 69 Tahun 2013 tentang Tarif Pelayanan Kesehatan Program Jaminan Kesehatan Nasional (JKN), ${ }^{21}$ Kemenkes telah menindaklanjuti usulan perubahan itu dengan menerbitkan Surat Edaran (SE) Menkes No. 31 dan 32 Tahun 2014.

Namun regulasi yang baru diterbitkan itu belum sampai ke Dinas Kesehatan dan Rumah Sakit (RS) di seluruh Indonesia. Secara keorganisasian ada perubahan yang signifikan dari lembaga sebelumnya yaitu PT Askes dan PT Jamsostek sebagai BUMN ke BPJS yang berbadan hukum publik. Dengan perubahan itu maka lembaga yang tadinya berorientasi profit menjadi non profit. Namun, bukan berarti BPJS tidak bisa mendapat surplus. Hal itu dibolehkan asal keuntungan yang diperoleh dikembalikan lagi kepada peserta untuk

21 Peraturan Menteri Kesehatan No. 69 Tahun 2013 tentang Tarif Pelayanan Kesehatan Program Jaminan Kesehatan Nasional. 
meningkatkan kualitas pelayanan. Dari sisi regulasi, pemerintah seharusnya dapat menanggung gelandangan, anak jalanan, anak panti asuhan, orang jompo dan penghuni lapas.

Rencananya, pemerintah menambah anggaran sebesar Rp 400.000.000.000,00, namun hal ini terhalang karena Perpres No. 111 Tahun 2013 tentang Jaminan Kesehatan, ${ }^{22}$ hanya mengakomodasi 86,4 juta rakyat miskin sebagai PBI. Padahal menurut BPS 2011, orang miskin ada 96,7 juta. Masalah lainnya terletak pada pelaksanaan di lapangan. Pelayanan kesehatan yang diselenggarakan oleh PPK I (Puskesmas dan klinik) maupun PPK II (Rumah Sakit) menunjukkan masih ditemukan pasien yang harus mencari kamar karena banyak RS yang bilang penuh.Selain itu, banyak pasien yang sudah sekarat harus mencari ruang ICU/ICCU. BPJS Kesehatan seharusnya lebih sensitif dan peduli untuk masalah-masalah teknis. Harusnya ada desk khusus BPJS Kesehatan di tiap RS yang memiliki data atau informasi ter-update terkait masalah ketersediaan ruang rawat atau ruang ICU/ICCU di RS lain.

Desk khusus tersebut online dengan desk khusus BPJS di RS-RS lain sehingga BPJS kesehatan akan menginformasikan lebih pasti mana RS yang memiliki ruang rawat atau ICU/ICCU kosong, dan beroperasi 24 jam dan terus memantau ketersediaan ruangan perawatan atau ICU/ICCU dimasing masing RS. Selain itu, permasalahan darah BPJS Kesehatan harus mempunyai kerja sama khusus dengan PMI atau RS lain yang mempunyai stok darah, sehingga ketika pasien membutuhkan hal tersebut dapat terpenuhi. Hingga kini masih banyak Puskesmas atau Rumah Sakit yang masih menggunakan sistem manual dalam pelayanan BPJS Kesehatan. Hal ini mengakibatkan risiko klaim ganda dan double kepesertaan pun tak bisa dihindarkan, karena akan membuat BPJS Kesehatan bangkrut.

Risiko klaim ganda dan double data peserta hanya dapat dikontrol dengan sistem online di seluruh lapisan BPJS Kesehatan, baik di pelayanan kesehatan tingkat primer hingga tersier. Sehingga data peserta bisa dapat segera diakses jika yang bersangkutan sedang berobat. Dari sekitar 9.600 Puskesmas yang tersebar di Indonesia misalnya, baru Puskesmas di DKI Jakarta yang dikatakannya telah 
menggunakan sistem online yang baik. Risiko lainnya ialah, penyalahgunaan kartu anggota oleh orang lain.Risiko ini, sangat banyak terjadi dalam Jaminan Kesehatan Masyarakat (Jamkesmas) yang diterapkan sebelumnya.

\section{Penutup}

Berdasarkan uraian di atas, diperoleh kesimpulan bahwa pelaksanaan UU No. 40 Tahun 2004 terkait Jaminan Sosial Kesehatan pasca Putusan MK No. 07/PUU-III/2005 yang pelaksanaannya dipercayakan pada BPJS Kesehatan masih jauh dari makna keadilan. Penerapan BPJS Kesehatan masih memiliki persoalan dalam banyak hal, di antaranya karena menerapkan alur pelayanan berjenjang yaitu sebelum ke rumah sakit, peserta wajib terlebih dulu ke fasilitas kesehatan tingkat pertama (Puskesmas). Masalah lain, adalah rumitnya alur pelayanan BPJS Kesehatan karena menerapkan alur pelayanan berjenjang.

\section{Daftar Pustaka}

Dwiyanto, Agus, MewujudkanGood Governance Melalui Pelayanan Publik, Cetakan pertama, Penerbit Gadjah Mada University Press, Yogyakarta, 2005.

Garna, Judistira, K., Metode Penelitian Sosial: Penelitian Dalam Ilmu Pemerintahan, I. Desain dan Rencana Penelitian, Primaco Akademika, Bandung, 2000.

Hassan, M. Iqbal,Pokok-Pokok Materi MetodologiPenelitian, Penerbit Ghalia Indonesia, Jakarta, 2002.

John W.Creswell, Researh Design. Quanlitative EQuantitative Approache, Sage Publication, Inc, New York 2002.

Moleong, Lexy, J., Metodologi Penelitian Kualitatif, Remaja Rosda Karya, Bandung, 2005.

Prakoso, D., Hukum Asuransi Indonesia, PT. Asdi Mahasatya, Jakarta, 2004.

Sugiyono, Metode Penelitian Bisnis, Penerbit Alfabeta, Bandung, 2012.

Soekamto, dkk, Reformasi Sistem Jaminan Sosial di Indonesia, Social Health Insurance Project Indonesia, 2006.

Sekretariat Jenderal MPR RI 2015, Undang Undang Dasar Negara Kesatuan Republik Indonesia Tahun 1945, Cetakan Keempatbelas, Juni 2015. 
Thoha, Miftah, Birokrasi Pemerintahan Indonesia di Era Reformasi, Kencana Prenada Madia Group, Jakarta, 2008.

Ubaedillah, A. dan Abdul Razak, Pendidikan Kewarganegaraan (Civic Education): Demokrasi HAM dan Masyarakat Madani, Edisi Ke tiga, Penerbit Kerjasama ICCE UIN Syarif Hidayatullah Jakarta dan Prenada Media Group, Jakarta, 2010.

Yuliandri, Asas-Asas Pembentukan Peraturan Perundang-undangan yang Baik, Cetakan Pertama, PT RajaGrafindo Persada, Jakarta, 2009.

Amandemen Undang Undang Dasar Negara Kesatuan Republik Indonesia Tahun 1945.

Ketetapan MPR RI No. X/MPR/2001 tentang Laporan Pelaksanaan Putusan MPR RI oleh

Lembaga Tinggi Negara pada Sidang Tahunan MPR RI Tahun 2001.

Undang-Undang No. 32 Tahun 2004 tentang Pemerintahan Daerah.

Undang-Undang No 40 Tahun 2004 tentang Sistem Jaminan Sosial Nasional (SJSN).

Undang-Undang No. 24 Tahun 2003 tentang Mahkamah Konstitusi.

Undang-Undang No. 6 Tahun 1974 tentang Ketentuan-ketentuan Pokok Kesejahteraan Sosial

Undang-Undang No. 2 Tahun 1992 tentang Usaha Perasuransian.

Undang-Undang No. 2 Tahun 1992 tentang Jaminan kesehatan bagi PNS melalui PT Askes.

Undang-Undang No. 6 Tahun 1966 tentang Jaminan Hari Tua dan Pensiun bagi TNI/Polri melalui PT Asabri.

Undang-Undang No. 36 Tahun 2009 tentang Kesehatan.

Konvensi ILO No. 102 Tahun 1952 tentang Unemploment Benefit.

Undang-Undang No. 11 Tahun 1969 tentang Pensiun Pegawai dan Pensiun Janda/Duda.

Undang-Undang No. 8 Tahun 1974 tentang Pokok-Pokok Kepegawaian jo. Undang-Undang No. 43 Tahun 1999 tentang Perubahan Atas Undang-Undang No. 8 Tahun 1974 tentang Pokok-Pokok Kepegawaian.

Peraturan Presiden No. 111 Tahun 2013 tentang Jaminan Kesehatan.

Peraturan Menteri Kesehatan No. 69 Tahun 2013 tentang Tarif Pelayanan Kesehatan Program Jaminan Kesehatan Nasional.

Peraturan Menteri Kesehatan Nomor 527/Menkes/Per/ VII/1993tentangJaminan Pemeliharaan Kesehatan Masyarakat (JPKM). 